\title{
On managing hypocrisy: The transparency of sustainability reports
}

\author{
Authors/Affiliation
}

Colin Higgins, Department of Management, Deakin University, Geelong, Australia

Samuel Tang, School of Business and Management, Queen Mary University of London, UK

Wendy Stubbs, School of Social Sciences, Monash University, Melbourne, Australia

Declarations of interest: none 


\title{
ON MANAGING HYPOCRISY: THE TRANSPARENCY OF SUSTAINABILITY REPORTS
}

\begin{abstract}
Hypocrisy creates significant challenges for managers and stakeholders. Knowledge of its nature and causes is extensive; however, understandings of its implications for management practice are limited. This study draws on the transparency literature, notably Schnackenberg and Tomlinson's (2016) disclosure, clarity and accuracy framework, to show that the way in which information is presented affects the way hypocrisy manifests and how it can be addressed. We analysed the sustainability reports of three financial services companies in Australia over a five-year period and found that in addition to minimising duplicity, transparency can increase engagement with the competing expectations facing companies. Despite its limitations, sustainability reporting offers insights in to the nature, causes and implications of organisational hypocrisy.
\end{abstract}

Keywords: Transparency; Hypocrisy; Sustainability reporting; Organised Hypocrisy. 


\section{ON MANAGING HYPOCRISY: THE TRANSPARENCY OF SUSTAINABILITY REPORTS}

\section{Introduction}

It is easy to find examples of organisations being caught saying one thing and doing another. Sometimes, there is clear duplicity, as there was as with the Volkswagen emissions scandal (Cavico \& Mujtaba, 2016). Sometimes, there are inconsistencies in how organisational values have been applied; for example, some organisations have committed to sustainability but continued to engage in damaging environmental practices (Klein, 2014). Sometimes, executives speak publicly about issues (e.g., good Human Resource practices) but fail to meet the standards they themselves set (Foote, 2001). Additionally, in some instances, business organisations have produced glowing sustainability and annual reports, despite the underlying performance of the organisations being poor (e.g., the Enron case; see Kulik, 2005). Consequently, considerable research has been conducted to gain an understanding of the nature, causes and implications of organisational hypocrisy (Cho, Laine, Roberts \& Rodrigue, 2015; Fassin \& Buelens, 2011; Greenbaum, Mawritz \& Piccolo, 2015).

Organisational hypocrisy is generally understood to involve a disconnect between talk and action (Brunsson, 2002; Wagner, Lutz \& Weitz, 2009). Most commonly, hypocrisy describes a situation in which an organisation has been deliberately presented in a way that differs to its underlying reality (Lyon \& Montgomery, 2015). This type of hypocrisy is viewed as duplicitous and is often purposefully undertaken to secure strategic outcomes (Deegan, 2002; Laufer, 2003). Less common, but attracting increasing attention, is organised hypocrisy (Brunsson, 2003). This type of hypocrisy is considered both inevitable and a management reality. It arises because organisations are complex and do not have a simple 'reality' that can be unproblematically and objectively presented. Managers encounter complex, multiple (and 
irreconcilable) expectations about what an organisation is and what it should be doing. Unlike deliberate deception, organised hypocrisy is unavoidable (Christensen, Morsing \& Thyssen, 2013).

Those that view hypocrisy as a form of duplicity have suggested that it should be called out by stakeholders (Bowen, 2014; Parguel, Benoît-Moreau \& Larceneux, 2011) and avoided (Wagner et al., 2009). This could be achieved via better regulatory oversight (Delmas \& Burbano, 2011). However, such a simple approach overlooks the reality (and inevitability) of organised hypocrisy and the fact that the simple presentation of an underlying reality is not always possible. Proponents of organised hypocrisy essentially suggest that managers will continue to present organisations in ways that differs to (some views of) their performance via decoupling (Meyer \& Rowan, 1977) or erecting facades (Cho et al., 2015). However, these approaches fail to address the damaging consequences that can arise from the mismatch that stakeholders may experience (Walker \& Wan, 2012) and could exacerbate, rather than eliminate, the criticism that organisations face (Bowen \& Aragon-Correa, 2014). It is clear that while much is known about the nature of hypocrisy, its implications in terms of management practice are less clear.

This paper sought to contribute to understandings of how the hypocrisy issues that arise from duplicity and the challenges associated with organised hypocrisy can be managed. Specifically, this paper sought to explore whether sufficient detail can be communicated in sustainability reports to limit opportunities for duplicity and whether sustainability reports provides managers with the capacity to articulate and communicate about the competing expectations they face.

Research that focuses on sustainability reporting can provide invaluable insights in to the management of hypocrisy challenges. Sustainability reporting is a well-established practice 
(Higgins \& Larrinaga, 2014), particularly among large organisations, and is one of the primary ways in which firms communicate their commitments and information about their performance (KPMG, 1993, 1996, 1999, 2002, 2005, 2011, 2013). To date, very few scholars have considered the role of sustainability reporting in addressing hypocrisy challenges. Indeed, most scholars have only demonstrated how these reports represent legitimacy-seeking behaviour (Deegan, Rankin \& Voght, 2000) or how these reports are used to erect the facades that enable organised hypocrisy (Cho et al., 2015). Our approach differs to that of previous research, as we drew on the transparency literature to explore what makes disclosure effective. By doing so, we provide insights into how transparent sustainability reports can assist in the management of hypocrisy challenges related to both duplicity and competing expectations.

Transparency has not formed a large part of hypocrisy work to date (but see Morin, 2016). Thus, the present study is somewhat unique, because it links the principles of effective disclosure to understanding the nature, causes and implications of organisational hypocrisy. Transparency is concerned with ensuring that information is made available to those with the right to know, enabling stakeholders to make informed choices about an organisation's performance (Haufler, 2010). This focus shifts attention to the way information is presented and disclosed at the level at which hypocrisy situations often arise. We used Schnackenberg and Tomlinson's (2016) disclosure, clarity and accuracy framework to examine five years of sustainability reports (2011-2015) produced by three Australian financial services organisations. Our objective was to shed light on whether (and how) a commitment to (and the practice of) transparency contributes to the management of avoidable and inevitable hypocrisy challenges.

In this exploratory study, the three financial services firms are each a critical case (see Flyvberg, 2001, 2006 and the discussion in this paper in the Methods section below). Firms in 
this industry have been enthusiastic reporters of their economic, social and environmental performance (KPMG, 2013), but have also been significantly (and consistently) associated with hypocrisy issues. In Australia, at the time of writing this paper, a Royal Commission into Misconduct in the Banking, Superannuation and Financial Services Industry had recently concluded $^{1}$. The Commission revealed widespread issues of poor organisational conduct, systemic governance failures and problematic organisational cultures (Commonwealth of Australia, 2019). The findings showed clear duplicity in how the organisations presented themselves in their sustainability reports. The findings also revealed the types of conflicting circumstances that give rise to organised hypocrisy: financial services firms play a significant role in the overall health of the economy, but also have important effects on consumers and their wellbeing and the social and environmental fabric of the economy via their lending activities.

Initially, we found that the reports we studied did little to address hypocrisy issues. However, by examining what is reported and how, our transparency-focused research shows that the lack of specificity around the report audience and purpose hinders the clarity and accuracy of the information presented and reported. These limitations provide fertile ground for hypocrisy challenges to flourish. A commitment to transparency can offer improvements in to how reporting practice, the regulatory environment, and also reporting guidelines could address some hypocrisy challenges. We also show that a lack of attention by organisations to transparency contributes to how hypocrisy situations emerge, providing new insights in to the nature and causes of hypocrisy challenges.

\footnotetext{
${ }^{1}$ For more details, see https://financialservices.royalcommission.gov.au/Pages/default.aspx.
} 
This paper is structured as follows. In the next section, we discuss organisational hypocrisy and expand upon our point that duplicity differs from organised hypocrisy. We also show that both present important challenges that are difficult to address. By situating our discussion within the transparency literature and highlighting the information characteristics that represent a threshold for effectiveness, we explore how hypocrisy challenges can be managed. Next, a brief overview of sustainability reporting is provided and the approach adopted in the present study outlined. This section includes a detailed discussion of the nature of hypocrisy challenges confronting the financial services industry. Following this, we outline and discuss our findings. Finally, we conclude the paper by making a number of suggestions as to what could be improved at the micro-organisational level, as well as in reporting practice more generally, in order to address hypocrisy challenges.

\section{Background and Literature Review}

\subsection{Hypocrisy}

Much has been made of the duplicity and lies that characterise how organisations communicate (Jahdi \& Acikdilli, 2009). When organisations engage in 'greenwashing' (Bowen \& Aragon-Correa, 2014; Siano, Vollero, Conte \& Amabile, 2017) or employ legitimacyseeking behaviours (Deegan, 2002), they are considered hypocritical (Lyon \& Montgomery, 2015), as their symbolic expressions of conduct differ to their actual behaviours (Walker \& Wan, 2012). It is thought that organisations largely engage in such actions to appear responsive to stakeholders (Ramus \& Montiel, 2005), to demonstrate their 'green' credentials (Delmas \& Burbano, 2011), in response to peer pressure within industries (Delmas \& Toffel, 2008) and as the result of unethical management practices (Brass, Butterfield \& Skaggs, 1998). This type of hypocrisy is viewed as a choice organisations make to deceive (Laufer, 2003) that needs to be called out (Parguel et al., 2011) and eliminated (Wagner et al., 2009). 
The notion that organisations are led (intentionally or unintentionally) to engage in organised hypocrisy or must communicate differently to appease multiple (and often conflicting) expectations casts such inconsistencies in a different light (Lipson \& Weaver, 2008). According to Brunsson (2003) organisations are typically viewed as co-ordinated and organised and as having a clear sense of what they are and should be doing. However, the reality is often quite different. Bromley and Powell (2012) and Crilly, Zollo and Hansen (2012) showed that firms need to secure legitimacy from divergent stakeholders with contrasting expectations (Slawinski \& Bansal, 2015). Organisations must appear rational (with wellorganised operating processes), respond to the latest trends, which may range from trends related to sustainability, lesbian/gay/bisexual/transgender and/or intersex (LGBTI) or worklife balance, be authentic (Alhouti, Johnson \& Holloway, 2016; Joo, Miller \& Fink, 2019) and also appear to be focused on value creation and profitability. Reconciling these is not always an option. In reality, organisations create (at least) two sets of structures and processes (Brunsson, 1993) or façades (Cho et al., 2015) that enable them to respond to expectations in different ways, while also appearing to conform. Rather than representing hypocrisy as duplicity, such decoupling (Meyer \& Rowan, 1977) or buffering (Thompson, 1967) is inevitable and unavoidable.

Both types of hypocrisy are challenging. For stakeholders organisations are opaque. Stakeholders have a right to know about an organisation's activities (Gray, Owen \& Adams, 1996) and also need clarity about an organisation's commitments and performance if they are to make informed choices (Laufer, 2003). The inevitability of organisational hypocrisy can create challenges for managers. Even in the absence of any intent to deceive, managers must decide whether to discuss the competing expectations they face or disguise them (Cho et al., 2015; Scandelius \& Cohen, 2016). There is an implied assumption that conflicting expectations 
need to be reconciled and any related decisions hidden (Brunsson, 2003). Currently, understandings about how managers can address such challenges are limited.

\subsection{Transparency}

A commitment to (and the practice of) transparency offers potential solutions to the hypocrisy issues experienced by stakeholders and the challenges faced by managers (Dubbink, Graafland \& van Liedekerke, 2008). Transparency is not new (Hood, 2006); however, it is almost universally considered desirable (das Neves \& Vaccaro, 2013). Transparency is effective at delivering a number of outcomes (Roberts, 2009). Transparency is assumed to provide the means for information disclosure that aids stakeholders in their understandings of organisations and how they are presented (Strathern, 2000).

In government, transparency forms the basis of information disclosure and freedom of information legislation (Christensen \& Cheney, 2015; Fox, 2007). It also forms the basis of scorecards and rankings in schools (e.g., Meijer, 2013) and hospitals (e.g., Hibbard, Stockard \& Tusler, 2003). Further, as more information leads to better informed citizens, transparency is also viewed as pivotal in reshaping the balance of power in society (Mol, 2010). In business, transparency can deliver operational improvements (Vishwanath \& Kaufmann, 2001), contribute to the effective functioning of markets (Bushman, Piotroski \& Smith, 2004; Dingwerth \& Eichinger, 2010; Kurtzman, Yago \& Phumiwasana, 2004) and build trust between organisations and stakeholders (Norman, Avolio \& Luthans, 2010; Schnackenberg \& Tomlinson, 2016). Examples of transparency include the Toxic Release Inventory (Fox, 2007; Tietenberg, 1998), product labelling (Meise, Rudolph, Kenning \& Phillips, 2014; van Dorp, 2003) and sustainability reporting (Dando \& Swift, 2003).

We considered whether sustainability reporting has the potential to offer sufficient capacity to identify duplicity and whether a commitment to transparency enables managers to address 
the competing expectations they face. Many researchers have cast doubt on the value of sustainability reporting (Gray \& Milne, 2002; Milne \& Gray, 2007; Milne, Tregida \& Walton, 2004), noting that organisations can (and do) manipulate transparency (Schnackenberg \& Tomlinson, 2016), including sustainability reports (Catalyst, 2015). However, few studies have explored the potential of sustainability reporting to address hypocrisy challenges through a transparency lens (Fernandez-Feijoo, Romero \& Ruiz, 2014). To date, most studies have emphasised legitimacy (Deegan, 2002), institutionalisation (Higgins \& Larrinaga, 2014) and stakeholder management (Ngu \& Amran, 2018) as motives for reporting. Consequently, their recommendations for improvements have focused on institutional and regulatory reform and the need for materiality assessments (Eccles, Krzus, Rogers \& Serafeim, 2012), reporting standards (Albu, Albu, Dumitru \& Dumitru, 2013) and assurance and verification (O'Dwyer \& Owen, 2005).

The adoption of a transparency lens focused this study on the design and structure of sustainability reports and the characteristics of the information reported. This lens went beyond simply detailing principles of reporting (e.g., balance, comparability, accuracy, timeliness, clarity and reliability; see GRI [2006] ) to considering what each of these involve. When considered in relation to the challenges of hypocrisy, the transparency of sustainability reports offers new insights in to how these reports can be structured and how information can be presented to overcome accusations of duplicity. It also provides a way of navigating competing expectations.

2.2.1 Effective Transparency. To be effective, transparency initiatives must be carefully structured. A one-size-fits all approach to transparency does not work (Dingwerth \& Eichinger, 2010). The objectives must also be considered in terms of specific instances of market or regulatory failures (Loewenstein, Sunstein \& Golman, 2014). Further, the targets of 
transparency (in governments and business organisations) (Williams, 2008) and what stakeholders, citizens or customers are expected to do with the information disclosed (e.g., to demand regulatory change or specific operational changes) (Kosack \& Fung, 2014) must be planned. Consideration must also be given to the specific characteristics (i.e., disclosure, clarity and accuracy) of the information produced (see Schnackenberg \& Tomlinson, 2016).

Disclosure refers to the relevancy (Williams, 2008; Nicolaou \& McKnight, 2006), observability (Bernstein, 2012; Kaptein, 2008), completeness (Granados, Gupta \& Kauffman, 2010; Street \& Meister, 2004; Zhu, 2004) and timeliness (Bloomfield \& O’Hara, 1999; Philippe \& Durand, 2011) of the shared information. Stakeholders' perceptions of transparency depend on information being openly shared in a timely manner. Further, the topics and material included should be consistent over time to allow stakeholders to observe stability or changes in performance and practices and show progress towards strategic targets between years or between organisations. However, disclosure refers to "more than the open transfer of all available information' (Schnackenberg \& Tomlinson, 2016, p. 1792). To address instances of organised hypocrisy, the needs of a target audience must be considered (Clark Williams, 2008), as well as the proportionality and relative materiality of the shared information to the organisation's strategy and business model. Organisations can address claims of duplicity by disseminating a balanced account of their performance that examines both positive and negative outcomes. Organisations reduce disclosure and transparency if they omit relevant information or change the topics included in their reports from year to year. Stakeholders are more likely to perceive duplicity when organisations provide an incomplete account or provide information that is out of date.

Clarity 'differs from disclosure in that it is largely about the seamless transfer of meaning from sender to receiver rather than the amount or relevance of information shared' 
(Schnakenberg \& Tomlinson, 2016, p. 1793). Clarity relates to coherence (Miller, 1996), interpretability (Nicolacu \& McKnight, 2006), understandability (McGaughey, 2002; Street \& Meister, 2004) and comprehensibility (Briscoe \& Murphy, 2012; Granados, Gupta \& Kauffman, 2010; McGaughey, 2002). Stakeholders perceive transparency when information is coherent, lucid and readily digestible, as this enables them to fully ascertain the value of the information. Common issues arise in relation to the measures used and the context in which information is presented. Organised hypocrisy may emerge if an organisation fails to connect shared information to their strategy and industry performance, as this limits stakeholders' ability to contextualise and comprehend the organisation's commitments and performance. Further, organisations reduce clarity and transparency and open themselves up to charges of duplicity if they overuse or strategically use technical and complex language that stimulates confusion and ambiguity among stakeholders, who may or may not be familiar with organisational processes, routines and jargon (Crilly, Zollo \& Hansen, 2012).

Accuracy is also essential and requires the careful consideration of the relationship between meaning, comprehensibility and bias (Granados, Gupta \& Kauffman, 2006; Vorauer \& Claude, 1998). As Schnackenberg and Tomlinson (2016, p. 1,794) stated, 'accuracy is unique to disclosure and clarity in that it is about information reliability rather than completeness or understandability'. Accuracy does not imply that information must be completely correct, as achieving that is impossible (Schnackenberg \& Tomlinson, 2016). However, 'material claims should reflect precise qualifications about their expected validity for information to be considered transparent' (Schnackenberg \& Tomlinson, 2016, p. 1793). Organisations can convey honesty and integrity to stakeholders by demonstrating that information is well founded (Bushman, Piotroski \& Smith, 2004), free of bias (Nicolacu \& McKnight, 2006; Williams, 2005), correct (Singh \& Sirdeshmukh, 2000; Street \& Meister, 2004) and by describing the 
measurement techniques and calculations underlying the information shared as necessary (Eijffinger \& Geraats, 2006; Philippe \& Durand, 2011). Accuracy is essential to reducing suspicions of 'greenwashing', legitimacy-seeking behaviours and other forms of duplicity, as it allows stakeholders to ascertain the actual impacts of the organisation. It is also critical in setting out the context and issues that the organisation needs to address. Organisations decrease accuracy and transparency by faking and decoupling. In doing so, they diminish 'the extent to which information conforms to the beliefs, logic structures, and lived experiences of the source' (Schnackenberg \& Tomlinson, 2016, p. 1,800). Organisations can reduce issues of organised hypocrisy by building rapport with stakeholders, hiring authentic leaders (Walumbwa, Luthans, Avey \& Oke, 2011), having third parties audit the information shared.

\section{Methods}

As stated above, this study analysed the sustainability reports produced by three Australian financial services firms over a five-year period through Schnackenberg and Tomlinson's (2016) transparency framework (see Table 3). We purposefully selected organisations that had been reporting for some time, were acknowledged leaders in reporting, but that had also faced challenges from stakeholders regarding their performance (duplicity) and/or the reality of competing expectations (an issue that may lead to organised hypocrisy).

Our focus on three financial services organisations was motivated by the need to select 'critical cases' (Flyvbjerg, 2001; Flyvbjerg, 2006). A critical case has strategic importance to the general research problem. The aim is to strategically select cases that provide broader insights into a research problem than what random selection would afford. In this study, cases were identified whose features had the most potential to provide wider insights into the specific research question. In this case, it was anticipated that we would be most likely to find evidence of the potential of sustainability reporting in organisations that faced the most scrutiny and 
which were deemed effective and leading reporters. If no evidence of transparency and its effectiveness in organisations whose reporting is the most mature can be found, questions should be asked as to whether sustainability reporting has any potential in this area.

Organisations operating in the financial services sector represent critical cases. Like many other firms, Australian financial services firms have come under intense scrutiny since the Global Financial Crisis of 2007-2009 (Glynos, Klimecki \& Willmott, 2015; Herzig \& Moon, 2013; Liu, 2015). Globally, concerns have arisen about the poor culture within the industry (Wishart \& Wardrop, 2018), regulatory safeguards (Schmulow, Fairweather \& Tarrant, 2019), oversights of banking products and services, risk-taking behaviours, and poor corporate governance (Adams, Borsellino, McCalman \& Young, 2017). Calls for greater transparency have repeatedly been made in this sector (Compass, 2010). Additionally, systemic and localised issues have given rise to charges of duplicity and have also lead to organised hypocrisy.

Numerous examples exist of localised issues or inconsistencies in the stated values of particular firms and how these have been reflected in practice. Table 1 provides examples of Australian banking scandals throughout the study period (see Karp, 2016, for a full list and more details about these scandals).

\section{Insert Table 1 about here}

The 'Big 4' banks in Australia (i.e., National Australia Bank [NAB], the Australian and New Zealand Banking Group [ANZ], the Commonwealth Bank of Australia [CBA] and Westpac) have produced sustainability reports (and other associated communications) for some time. Indeed, several banks, including the NAB, have won awards for their reports (Catalyst, 2015), while others have been lauded as model corporate citizens. For example Westpac was named 'the most sustainable company in the world' (Westpac Banking Corporation, 2015) and the ANZ was listed as a global banking sector leader in the Dow 
Jones Sustainability Index. When viewed in the context of the banking scandals above, these accolades raise clear issues of duplicity. As Catalyst (2015) stated, 'a schism exists between symbolic and substantive sustainability efforts' (p. 4). Perhaps most evident is hypocrisy as duplicity, as the banks are aware of many of the issues (Leo \& Roddam, 2017).

The banking and financial services sector also suffers from systemic issues that raise a 'moral conundrum' due to competing expectations (Catalyst, 2015, p. 10) and give rise to organised hypocrisy. They are mostly private entities with a legal obligation to maximise shareholder value. Norms of short-termism, performance rewards and a focus on profit maximisation prevail (Catalyst, 2015). They are both firmly ingrained in the economy and loom large in the public domain (Schmulow et al., 2019). Commercial banks represent the third largest sector of the Australian economy, account for over $40 \%$ of the total market capitalisation of the Australian Stock Exchange (Liu, 2015) and represent \$AUD 522 billion in Australian household deposits (or approximately one third of Australia's Gross Domestic Product [GDP]) (Catalyst, 2015). Australian banks fund most of the assets in the economy and a significant proportion of Australian banking stock is owned by Australian superannuation funds (Schmulow et al., 2019). The spill-on effects for the economy as a whole mean that they are 'too big to fail' (Scholtens, 2009). As Australian banks have tightened lending recently, the housing market, government stamp duty revenue and consumer confidence have declined.

Systemic issues raise the inevitability of organised hypocrisy, as banks and other financial services organisations must appear legitimate and responsible to the public and regulators, but also meet the profit and growth expectations of shareholders. As a 'banking culture' has given way to a 'sales culture' (Liu, 2015), banks have sought to 'paper over the 
cracks' and balance conflicting expectations about shareholder profits with their social and environmental commitments (Catalyst, 2015).

The three organisations analysed in this study comprised a large commercial bank, a superannuation fund and a smaller mutual society/community bank (see Table 2). Qualitative, multiple case studies of these three organisations ensured that the results would span the sector and also offer sufficient depth of reporting experience. This case study approach also enabled the research results to be placed within an organisational context and for the complex phenomenon to be analysed from different angles (Eisenhardt, 1989; Yin, 1984). In addition, our consideration of multiple cases provided opportunities to compare (and thus validate) ideas or inferences arising from each case and enabled us to propose new practical insights and inform theory development about the nature, causes and implications of organisational hypocrisy (Bansal \& Roth, 2000; Yin, 1984).

Table 2 summarises the characteristics of the three organisations selected for the detailed analysis.

\section{Insert Table 2 about here}

Our primary data source comprised 14 sustainability reports, ${ }^{2}$ published by three firms between 2011 and 2015. The analysis involved a qualitative content analysis (Bryman \& Bell, 2003) that was informed by Schnackenberg and Tomlinson's (2016) transparency framework. Content analysis is frequently used in case studies (Kolbe \& Burnett, 1991) and to analyse sustainability reports (Beck, Campbell \& Shrives, 2010). Such analyses provide a

\footnotetext{
${ }^{2}$ Bank Australia issued a report in 2011; however, this report is not publicly available.
} 
systematic and objective description of the content that improves the rigor, validity and reliability of the case study approach (Krippendorff, 2013).

Our research study comprised three stages. First, two of the three authors independently read through all 14 reports, identifying aspects of report structure and disclosures and gaining an overall 'feel' as to how 'easy' each report was to navigate. In the second more detailed phase, the two authors independently coded the content of the reports according to Schnackenberg and Tomlinson's (2016) dimensions of disclosure, clarity and accuracy (see Table 3). Finally, the two authors compared and discussed their individual findings to review and realign their coding decisions and (where necessary) recode the text in accordance with this discussion.

To improve intercoder reliability (or inter-rater reliability), various measures were implemented. First, adopting the approach of Miles and Huberman (1994), a detailed description of each dimension of disclosure, clarity and accuracy was drafted (see Table 3). This codebook assisted the data analysis and contributed to the standardising of the coding process. Second, the two authors blindly coded three reports using the same categorisation grid. The intercoder reliability was analysed by comparing the coding judgements of the two authors concerning the categorisation of the three reports (Harry, Sturges \& Klingmer, 2005). Adopting the approach of Miles and Huberman (1994) and Saldaña (2010), a coding consensus was reached when the authors achieved more than $85 \%$ agreement ${ }^{3}$ on $95 \%$ of the codes.

\footnotetext{
${ }^{3}$ To calculate a percentage agreement for intercoder reliability, we used the formula of Miles and Huberman (1994): reliability = number of agreements / number of agreements + disagreements. However, it should be noted that while "there is no standard or base percentage of agreement amount qualitative researchers, $[\ldots]$ 85-90\% range seems a minimal benchmark to those most concerned with an evidentiary statistic' (Saldaña, 2010, p. 28).
} 


\section{Insert Table 3 about here}

An issue arose in relation to the amount of data reported and the numerous examples uncovered. Careful consideration was given as to how best to make sense of and share the insights discovered. In the findings section, we present illustrative examples of some of the most salient issues that clearly suggest the transparency potential of sustainability reports in addressing hypocrisy challenges. This focus also enabled us to identify the areas to which specific improvements could be made to reporting practices and reporting guidelines.

\section{Findings}

In this section, we discuss our findings in relation to the framework of disclosure, clarity and accuracy. One issue that arose across all of the reports related to the lack of specificity regarding each report's audience and purpose and what was expected of the stakeholders. We return to this point in our discussion, but note that this issue is fundamental to the effectiveness of transparency initiatives (Dingwerth \& Eichinger, 2010; Kosack \& Fung, 2014; Loewenstein et al., 2014). As discussed below, this lack of specificity accounts for many of the weaknesses identified.

\subsection{Disclosure}

To reduce accusations of duplicity and provide a means for discussing competing expectations, a transparent sustainability report must provide sufficient detail to allow stakeholders to understand an organisation's impacts and the challenges that management face in running an organisation. Stakeholders need to be assured that the organisation has openly shared all the relevant information (positive and negative) in a timely manner (Schnackenberg \& Tomlinson, 2016).

Each report outlined each organisation's: values and purpose; businesses, products and services; social contributions; environmental stewardship; and leadership and governance. The 
information was mostly presented consistently over the five-year period for each company and also between the companies. Consistency aids observability and allows users to identify changes and analyse trends in performance over time (see Appendix A for an overview of the structure of each report). The introductory sections of the reports (typically entitled 'About Us') could provide scope to discuss the wider contexts in which these firms operate.

In each report, the organisations' discussions of their strategies and business models tended to be limited to how the organisations viewed themselves and what they aimed to achieve. For example, Bank Australia, noted that its customer-centric business model, which sought 'to enhance the economic wellbeing of its customers in responsible ways (2012, p. 3), was derived from its vision 'to be Australia's leading customer owed responsible bank' (2015, p. 5). Conversely, VicSuper referred to its 'not-for-profit and open to everyone' (2011, p. 2) business model, highlighted its products and services, some basic organisational statistics, its philosophy (goal, purpose, central operating principle and core values), recognition and the awards it had received. Finally, Westpac discussed its vision 'to be one of the world's great companies, helping our customers and people to prosper and grow' $(2012$, p. 6) and its strategic priorities.

None of the reports mentioned the trade-offs that had to be made to fulfil commitments or the tensions between profit maximisation, shareholder value and the role of the organisation in the economy. The incomplete accounts of all three organisations reduced disclosure (and perceived transparency). Discussion at the micro-level represents a façade, as while broader tensions and challenges are not necessarily masked, they are avoided, which suggests a degree of organised hypocrisy. This also represents a missed opportunity to outline the competing expectations these organisations face. Stakeholders could be forgiven for thinking that there were no fundamental conflicts between responsible and sustainable business and the role and place of organisations in the overall functioning of the economy. 
Disclosure was also reduced by which information the organisations chose to share. The reports were dominated by some issues (e.g. environmental stewardship), which are of little relevance to banks' stakeholders, and are of relatively low materiality to financial institutions. ${ }^{4}$ For example, VicSuper provided considerable detail about its paper usage. Indeed, in its 2011, 2012 and 2013 reports, VicSuper included a five-year time-series graph in relation to its total paper use (equivalent to millions of A4 sheets) and the total paper use (equivalent to A4 sheets) per member, noting that the paper used was 'either made with recycled content or comes from sustainable managed forests (as evidenced by Forest Stewardship Council)' (2013, p. 33). Similarly Bank Australia provided extensive detail about paper usage, transport for business purposes and the water and energy consumption of the buildings it owns or leases (but made very few statements about the businesses it finances). Westpac also disclosed performance figures and targets for office paper usage and recycling rates, but only in relation to its head office in Sydney.

This abundance of information about environmental issues implies engagement with and addresses wider societal expectations for environmental action; however, it arguably presents a façade that was used to divert stakeholders' attention from and scrutiny of material issues. Indeed, while details of paper usage address environmental commitments, they have less relevance to VicSuper's overall strategy than information about how it engages with the companies in which it invests (see Table 4).

\footnotetext{
${ }^{4}$ According to a report by the GRI and Robeco (2015), investors view the main material issues of a bank as risk management, corporate governance, human capital management (e.g., training and education), employment, diversity and equal opportunity. Environmental stewardship was found to have low materiality to bank investors. Further, the report also identified a shift away from environmental reporting in the sector, as 'more financial institutions are becoming aware of the need to focus on the real economy, and acknowledge that their main environmental impact is through financing and investments, not the direct environmental impact of their operations' (GRI, 2015, p. 19).
} 


\section{Insert Table 4 about here}

Despite growth in the fund, the number of companies engaged by VicSuper has fallen from 647 in 2011 to 540 in 2012 and 506 in 2013. Little information was provided as to why VicSuper engaged with fewer companies and very little information was provided as to the environmental, social and governance (ESG) issues related to this engagement. The omission of such relevant information raises questions about VicSuper's engagement approach, including whether the approach is so effective that very few issues exist or if information on engagement was omitted for another reason. No information was provided as to whether VicSuper is investing in 'unsustainable' companies. Other questions also arose, including what trade-offs do VicSuper consider in balancing the pressure for investment returns with identified ESG issues; are the same companies engaged each year about the same issues; and what are the outcomes of the engagement process. The absence of such details calls into question the completeness of the report, limits the relevance of the information provided and creates an impression that considerable efforts have been undertaken that are not commensurate with the evidence. Given VicSuper's stated commitments, this represents a degree of duplicity. Further, their use of façades prevents tensions from arising in relation to VicSuper meeting (or failing to meet) its commitments.

In terms of observability (i.e., the ability of stakeholders to identify changes and analyse trends in performance), fluctuations in what is reported, how it is measured and the method of presentation limit the potential of each report to overcome questions of duplicity. For example, in relation to the reporting of water data, Bank Australia's shifted from using simple qualitative measures in 2011 and 2012 to targets and time-series figures for absolute $\left(\mathrm{m}^{3}\right)$ and relative $\left(\mathrm{m}^{3} / \mathrm{FTE}\right)$ measures by 2014 . This change in the unit of measurement inhibits the ability of stakeholders to directly compare year-to-year performance. More alarmingly, from 2014, Bank 
Australia completely ceased to disclose any information about its governance structure. VicSuper reported a steady increase in carbon dioxide $\left(\mathrm{CO}_{2}\right)$ emissions between 2011 and 2013; however, despite its claims that it was prioritising carbon reductions, VicSuper ceased reporting on $\mathrm{CO}_{2}$ emissions in 2014 without explanation. VicSuper actions were similar in relation to its total electricity use. Similarly, Westpac reported on employee wellbeing, diversity and retention in 2012 and 2013, but did not discuss these topics in 2011, 2014 or 2015. Such inconsistencies and irregularities in reporting are likely to negatively affect stakeholders' perceptions of transparency, particularly in relation to observability and the timeliness with which information shared, which could raise suspicions of duplicity. Further, stakeholders may also question why disclosure has changed, what such changes mean and why it was necessary to change measures and priorities.

Some fluctuations are reasonable if strategies and priorities shift and/or stakeholders provide feedback about what they expect to see; however, the rationale for any changes must be outlined to improve observability. Changes to the information that is included or omitted year to year prevents completeness and hinders the ability of stakeholders to observe performance trends over time. In terms of relevance, granular improvements to reporting energy and electricity use are likely to be less relevant than improvements to more strategic commitments (e.g., engagement). In relation to making improvements to the data reported, organisations would be better advised to address hypocrisy challenges by focusing on strategic issues and by responding to and discussing conflicting expectations.

\subsection{Clarity}

Clarity refers to the ease by which a stakeholder can gain a clear picture of an organisation, its impacts, challenges and priorities (Schnackenberg \& Tomlinson, 2014). Clarity is critical in reducing duplicity and setting parameters for articulating the issues managers face, as it reduces 
ambiguity about the status of the organisation. To be effective, the information shared needs to be coherent, understandable, easy to interpret and presented as simply as possible.

The reports examined in the present study all included extensive data, but provided very little context to aid understandability. For example, VicSuper's and Westpac's reports on employee gender statistics included data on meeting internal targets (for VicSuper in relation to the balance of its workforce and for Westpac in relation to women in leadership positions), but did not discuss whether the data matched or exceeded agreed sector standards. It is neither clear nor easily comprehendible to the organisations' stakeholders how the targets compared to the sector or the business community more generally. Questions remain as to whether the targets are realistic and what steps need to be undertaken to achieve them. Further, the information shared by each organisation indicated that performance had been positive (yearon-year); however, it was unclear whether the organisations lag behind others or led the sector. Interested stakeholders may suspect duplicity if the organisations' gender targets and performances are ultimately discovered to be below sector standards.

The performance data also lacked detail about the initiatives driving performance. For example, in relation to gender, it was not clear whether the improvements were driven by specific initiatives or natural attrition. A stakeholder may be curious as to whether processes of positive discrimination are in place and as to what trade-offs have been made. The organisations gave the impression that progress is 'sound' and that they are responsive; however, the absence of context reduces clarity and perceived transparency, which in turn gives rise to organised hypocrisy.

Similar issues arose at Bank Australia in relation to its carbon emission data. Bank Australia provided emission reduction figures for 2012 and 2013; however, it was not clear what these figures meant in terms of organisational strategy. Further, no information was 
provided about the positive or negative consequences of other operations and processes related to emission reductions. This is likely to raise questions among stakeholders as to what tensions exist and what sacrifices have been made. Perhaps more significantly, there was also a lack of data about the scope of the funded projects (e.g., the number and range of the funded projects) and whether the offsets were achieved through careful integration across multiple funded projects or one large project. Additionally, there is a question as to whether reductions have occurred due to intentional actions or as an unintentional consequence. Failure to discuss such issues leaves organisations open to charges of organised hypocrisy. Knowledgeable stakeholders may have given leeway to the organisation had emissions increased.

Issues of gender equality and carbon emissions also raise issues about both duplicity and organised hypocrisy. Questions include: does the lack of context mask duplicity; are the organisations attempting to create an impression of responsiveness, but seeking to avoid their underlying activities being scrutinised; and do these issues reflect growing community and stakeholder pressures that managers find it difficult to address? Simple explanations of the choices made, which trade-offs were considered acceptable and the rationale for policies in these areas could enable these challenges to be managed more effectively and create opportunities for stakeholder dialogue.

One further issue that arose in the reports relates to a lack of specificity. For example, Bank Australia used the tagline 'Responsible Banking' consistently; however, the meaning of this phrase appeared to change throughout the report. Initially, the report focused on 'customer wellbeing', 'doing things differently' and Bank Australia's commitment to 'the achievement of a balanced set of outcomes that are in line with customers' expectations across our key areas of performance' (2011, p. 3). Data was presented alongside this headline message; however, there was no clear way to interpret this data. Indeed, it was not clear why or how the measures 
reflected 'balance', what was being balanced or whether the organisation engaged with its customers to determine their expectations. Consequently, Bank Australia appeared to be presenting a façade, as no detail was provided to aid understanding of the organisation's position. In 2012, Bank Australia indicated that 'customers were recently asked about their decision making and attitudes around banking products and services' (2012, p. 6). However, rather than explaining how this informed its investment decisions, Bank Australia merely stated customers are 'attracted to the bank because of its responsible reputation' (2012, p. 6). Similar fluctuations were observed in 2013 and 2014.

In relation to VicSuper's engagement with investee companies (see discussion above), despite indicating that a number of issues were addressed (an average of 1,306 issues per year), the sets of issues listed each year were identical: board structure, executive remuneration, operations in troubled regions, munitions manufacture, shareholder returns, carbon intensity, bribery. It is not surprising that similar issues arose each year; however, the absence of new issues raises questions as to the organisation's level of engagement. Numerous questions arise, including: does the organisation uncover new challenges as new knowledge is received; did no new issues arise; if the same issues continue to arise each year, how effective are the organisation's engagement efforts; what are the specific issues raised under each; and which issues are the most significant? Such information is important to members and investor stakeholders, especially in circumstances in which an organisation claims that these issues are at the centre of its purpose, strategy and objectives. The readers of such reports must have had the impression that considerable action has been undertaken, while being unable to identify exactly what had occurred.

Similar ambiguities arose in Westpac's reporting of environmental business activities. In Westpac's report, 'headline statements' prevailed and very little contextual data was provided 
to aid interpretability. In 2013, Westpac reported $\$ 6$ billion in lending and investment in CleanTech and the environmental services sector and noted that wind and solar projects had been funded; however, Westpac did not contextualise this in terms of its overall lending portfolio or in relation to any increases that it had made in its other less environmentallyfriendly investments. This issue is an excellent example of organised hypocrisy. However, Westpac did not simply engage with the issue as a façade (Cho et al., 2015); rather, it presented itself as self-evidently environmentally responsible. This lack of clarity continued in subsequent reports. Notably, its investments in CleanTech and environmental services exceeded \$6 billion in 2014 (reaching \$8 billion), but declined in 2015 .

\subsection{Accuracy}

The importance of accuracy is obvious; reports that contain inaccuracies cast doubt on the integrity of managers, organisations and reporting processes. Stakeholders expect information to be technically compliant with reporting regulations and standards and free from bias (Schnackenberg \& Tomlinson, 2016). Inaccuracies can give rise to suspicions of duplicity.

This study assumed that the information reported in each of the individual reports was accurate (notably, each report was independently verified). ${ }^{5}$ However, when each organisation's report was compared across the five years, inaccuracies in reporting were found between the years. Notably, differences were found in the comparative figures provided for numerous operational and strategic indicators. For example, VicSuper reported that it purchased $9.04 \mathrm{~m}$ sheets of paper in 2011, but the comparative data provided in the 2012 report for 2011 suggests that it purchased $8.95 \mathrm{~m}$ sheets of paper. Similarly, Westpac's paper usage for 2011 and 2012 was 6,262 tonnes and 6,030 tonnes, respectively; however, in the 2013

\footnotetext{
${ }^{5}$ Note: the organisations tended to change assurers across the time period studied.
} 
report, the figures for 2012 and 2011 had been adjusted to 1,579 tonnes and 'n/a' (i.e., not available), respectively. The organisations provided footnotes indicating that recalculations had occurred; for example, VicSuper (2012) wrote: 'Note: The figure for 2010/11 has been restated to amend a calculation error published in last year's report'. However, the lack of specific information about how the calculation was amended reduces accuracy (and perceived transparency). Thus, questions are likely to arise about the validity of other data statements in the current and previous reports and the precision of reporting.

Detail of VicSuper's and Westpac's paper usage is unlikely to be material; however, inaccuracies in VicSuper's engagement patterns could give rise to suspicions of duplicity. As noted above in the 'Disclosure' section, VicSuper disclosed its engagements with Australian and international companies. In 2011, it reported that it had engaged with 35 Australian companies, but the comparative figure provided for 2011 in the 2012 report was 53. Bank Australia's reports contain similar inaccuracies in relation to the comparative reporting of carbon emissions. A further lack of precision was observed in some of the labels used for quantitative indicators of performance. For example, Westpac changed from 'total paper usage-Aust \& NZ (tonnes)' in 2012 to 'office paper-Aust \& NZ (tonnes)' in 2013, without communicating whether this change represented a mere relabelling or if the underlying data collected was different.

Similar inaccuracies were observed in most of the reports across the years. If these inaccuracies were simple errors, it might seem minor and over critical to point them out; however, such errors cast doubt on the accuracy and trustworthiness of all the reported information. It may be that these inaccuracies represent adjustments and that such adjustments should be expected to occur as companies improve their data collection techniques or evolve their businesses (e.g., by selling assets and growing); however, none of the organisations 
explained any changes to their approaches. Diligent and regular readers of sustainability reports are likely to spot reporting inaccuracies and have questions about the precision and thus the validity and overall credibility of the organisation and its performance.

At worst, the inaccuracies represent attempts to deceive, which will do very little to reassure stakeholders that the organisations are not being hypocritical. Conversely, the inaccuracies may be symptomatic of the challenges managers face in ensuring their reports meet both changing stakeholders' expectations and the institutional environment. Maintaining accuracy over time is particularly difficult given that the delay between measuring, collecting and reporting data is often more than a year. During this time, stakeholders' expectations may change, which may unintentionally reduce the perceived integrity of what is reported and how.

\section{Discussion}

Initially, our findings suggested that sustainability reports have little potential to address the hypocrisy issues experienced by stakeholders (duplicity) and the competing expectations faced by managers (organised hypocrisy). We found several limitations in the information reported, how the information could be understood and the overall clarity and accuracy of the information. Like Dando and Swift (2003), it would be easy to dismiss sustainability reports as 'greenwashing' and a legitimacy-seeking exercise (Deegan, 2002) and to conclude that such reports do little to address organisational hypocrisy.

Duplicity is clearly a problem. We found that organisations' statements of vision were at odds with their performance as revealed by the recent Royal Commission in to Misconduct in the Banking, Superannuation and Financial Services Industry in Australia. For example, Westpac stated that their vision was 'to be one of the world's great companies, helping our customers and people to prosper and grow' (2012, p. 6); however, the Royal Commission revealed that Westpac had breached responsible lending laws, leading to substantial losses for 
many of its customers (Commonwealth of Australia, 2019). Recent banking scandals also revealed that Westpac faced a 2014 fine for misleading product disclosure statements, a 2015 series of refunds for unwanted insurance products and a 2016 fine over credit limit practices (Karp, 2016). Additionally, our study found that the lack of clarity and accuracy gives rise to suspicions of duplicity. For example, Bank Australia created an impression of action in relation to its carbon emission data; however, due to the lack of context provided, its actions could not be evaluated. It appears that very little has changed since Deegan's (and his colleagues') early research $(2000,2002)$ on the legitimacy motives of sustainability reports.

Organised hypocrisy also loomed large in our analysis. Notably, we identified a number of façades (Cho, Laine, Roberts \& Rodrigue, 2015) that decoupled (Meyer \& Rowan, 1977) and buffered (Thompson, 1967) organisations' performance from what might be expected of them. One such façade relied on the use of operational-level disclosures to mask the absence of detailed disclosures of strategic issues. For example, VicSuper's extensive reporting of paper and energy usage was given at the expense of detail about its engagement with its investee companies. Similarly, environmental responsiveness was used as a façade to mask activity around material issues.

Notably, GRI and Robeco (2015) suggested that issues of human capital (including employment, diversity and equal opportunity) are highly material to the banking and financial services industry and far outweigh the environmental impacts of these organisations' own operations. While Westpac set targets in relation to women in leadership positions, it failed to discuss whether the targets were realistic or how they related to the sector as a whole. This contrasted greatly to the manner in which it reported on the environmental impacts of its corporate headquarters. Additionally, the organisations used 'processes' as a façade in failing to detail the outcomes of the processes they disclosed. For example, Bank Australia discussed 
their customer and stakeholder engagement process, but failed to mention how the findings were used, the challenges that ensued or exactly what the organisation did as a result of the insights gained from this process. Such façades reinforce Cho et al.'s (2015) point that 'the prospects of sustainability reports developing into substantial disclosures is severely limited by organised hypocrisy' (p. 91).

The objective of this paper was not to highlight that sustainability reports enable hypocrisy but to show that sustainability reports may have the potential to address hypocrisy. There is an important gap in understandings of the management implications related to hypocrisy issues. As Jahdi and Acikdilli (2009) observed, the manner in which a company communicates 'can play a major role in conveying a company's [corporate social responsibility] messages and communicating a more socially responsible image' (p. 103), but its credibility and reliability may remain problematic. Thus, transparency provides insights in to how information can be reliably provided to enable stakeholders to make informed choices (Haufler, 2010). It also offers scope for addressing the hypocrisy issues stakeholders experience and the challenges managers face in seeking to improve the practice of disclosure.

Loewenstein, Sunstein and Golman (2014) explained that the effectiveness of transparency rests on targeting a specific problem, while Dingwerth \& Eichinger (2010) noted that a onesize-fits all approach does not work. Notably, our analysis revealed a lack of specificity in the sustainability reports examined. It was not clear whether these reports were an account of each organisation's performance against its stated commitments, reports to stakeholders in response to their feedback and expectations, or a catalogue of performance metrics against a standardised set of indicators (usually the GRI). This represent a significant limitation, but also reveals where potential areas of improvement lie. Initiatives, such as product labelling and the Toxic Release Inventory, are effective because they have a clear focus. Consumers are able to alter 
their consumption patterns on the basis of the information provided (Meise et al., 2014; Tietenberg, 1998).

To address hypocrisy, particularly organised hypocrisy, sustainability reports need to focus on engagement and dialogue. Rather than erecting façades to mask competing expectations, sustainability reports should seek to stimulate dialogue about challenging issues and competing expectations. As Kaptein and Van Tulder (2003) noted, this was an early intention of such reports, but it has long since been neglected. Sustainability reports could place an organisation's strategies and priorities in the context of the broader pressures it faces and be instruments for dialogue and compromise. However, this would require a greater commitment to the relevance and observability components of Schnackenberg and Tomlinson's (2016) disclosure. Rather than using the 'About Us' sections of the reports to focus exclusively on the organisation, these sections could be used to present the decisions and trade-offs organisations must make and the priorities that organisations must adopt as they navigate complex environments.

A clear sense of what stakeholders are expected to do is absent from sustainability reports but is necessary if these reports are to be effective (Williams, 2008). School and hospital rankings are effective because they reflect the intent of citizens to exert pressure on providers and stimulate public policy reform (Kosack \& Fung, 2014). If sustainability reports are to address hypocrisy challenges, the extensive (and somewhat opaque) disclosure on a wide range of topics needs to be connected to the interests of stakeholders and clear channels of action.

It may be more difficult to address the challenges associated with duplicity, as it is unlikely that organisations inclined towards deliberately misleading their stakeholders will enthusiastically embrace transparency. However, this study showed that some duplicity may arise due to a lack of clarity and accuracy in what is being reported and may not reflect 
deliberate attempts to mislead stakeholders. Suspicions of duplicity may also arise due to the amount of data being presented without context (e.g., Westpac's data on its investments in CleanTech), differences in how data is presented from year to year (e.g., Bank Australia's governance processes) and instances of data being omitted without explanation (e.g., VicSuper's data on carbon reporting). Sustainability reports that contain clear comparator data and a summary that details changes in reporting and reasons for such changes would aid transparency and minimise duplicity.

If duplicity is to be addressed, changes to reporting guidelines and reporting regulations may be necessary. For example, ambiguities about the content of reports, particularly confusion between GRI-inspired environmental data and more strategic contextual challenges may be attributable to the guidelines being used. The GRI has a significant effect on reporting practice and many organisations find the checklist approach irresistible (Dumay, Guthrie \& Farneti, 2010); however, this has also led to excessive details being included in reports. Similarly, the specification by the International Integrated Reporting Council as to how an organisation's business model should be described affects the organisation-centred nature of the 'About Us' sections. If sustainability reports are to address hypocrisy challenges, changes may need to be made to the requirements set out in reporting guidelines.

It is not contended that transparency offers a silver bullet. Schnackenberg and Tomlinson (2016) noted that their framework merely sought to offer opportunities to manage transparency and was not meant to be exhaustive. Disclosure, clarity and accuracy represent 'an initial set of approaches available to firms to manage specific aspects of transparency' (Schnakenberg \& Tomilinson, 2016, p. 1,801). Strict adherence to this framework will not solve every problem and it would be unrealistic to expect it to do so. However, this framework does provide a starting point for identifying issues, clarifying disclosure and reporting principles. This 
framework also places sustainability reporting in a broader context by providing details of effective information disclosure.

\section{Conclusion}

The objective of this paper was deliberately modest. We sought to examine the potential of a well-established management practice to address the hypocrisy issues that arise from duplicity and the challenges associated with organised hypocrisy. Organisational hypocrisy is clearly a significant issue. Poor and misleading disclosures cause stakeholders to suffer and may lead to managers being backed in to corners as they grapple with competing expectations. However, while much is known about the nature and causes of organisational hypocrisy, very few theoretically robust options have been developed to address its implications for management.

By drawing on the transparency literature and undertaking an in-depth examination of sustainability reports, we offered a new lens through which hypocrisy could be understood and addressed. We showed that sustainability reports, as they are currently structured, have not shifted far from being largely a legitimacy-seeking exercise; however, such reports still have potential. For example, these reports could be used to create a dialogue around competing expectations. Such an approach would likely reduce façades, buffering and decoupling.

This study's focus on transparency also showed that unintentional duplicity could be avoided if greater care was taken and some basic principles were adopted. By situating our examination of sustainability reports within the wider transparency literature and by adopting a longitudinal approach to five consecutive years of reporting, this study showed that a careful focus on particular audiences, the objectives and scope of disclosure and a clear set of actions that stakeholders could pursue would help to address some of the hypocrisy issues that arise. 
However, it should be noted that we do not suggest that transparency offers an easy solution to hypocrisy challenges or that sustainability reporting is not problematic. Indeed, there is a need for broader institutional and regulatory reform (Cooper \& Owen, 2007) and further research needs to be undertaken. We know that transparency flourishes in a well-developed ecosystem that comprise active media, committed executives and targeted and sophisticated regulations (Etzioni, 2010; van Zyl, 2014). However, the question arises: what mix of organisational, voluntary and regulatory instruments would stimulate such an ecosystem? Rather than regulations that require sustainability reporting, it may be that regulations should focus on what is reported and how. Further, reporting guidelines that provide more sophisticated options for defining the purpose and scope of reports are needed. The GRI and others have developed sector supplements that enable targeted reporting in different sectors; however, guidelines for different reporting purposes, including hypocrisy, should also be considered. At the organisational level, it is clear that the burden of data collection, analysis and presentation is high (Higgins, Milne \& van Gramberg, 2015). This has likely led to inaccuracies and the most convenient indicators and measures being selected. More work needs to be undertaken to simplify data collection procedures to reduce errors and inaccuracies in the information reported.

The idea that hypocrisy can simply be avoided (Wagner et al., 2009) or accepted (Christensen et al., 2013) overlooks the nuances associated with how hypocrisy is received and interpreted by stakeholders. Our close reading of a set of reports intended for external consumption showed how report structure, presentation and the choices associated with information disclosure affect perceptions of hypocrisy. More work needs to be undertaken to engage with stakeholders directly to understand how reporting shapes their judgements and perceptions about organisations and their hypocrisy. A stakeholders perspective on how 
hypocrisy manifests and is managed would increase understandings of the nature, causes and implications of this challenging organisational phenomenon. 


\section{References}

Adams, M., Borsellino, G., McCalman, J., \& Young, A. 2017. Australia's proposed Banking Executive Acountability Regime: Regulatory panopticon or fail-safe? Governance Directions, 69(9): 528-531.

Albu, N., Albu, C., Dumitru, M., \& Dumitru, V. 2013. Plurality or convergence in sustainability reporting standards. Amfiteatru Economic Journal, 15: 729-742.

Alhouti, S., Johnson, C. M., \& Holloway, B. B. 2016. Corporate social responsibility authenticity: Investigating its antecedents and outcomes. Journal of Business Research, 69(3): 1242-1249.

Bansal, P., \& Roth, K. 2000. Why companies go green: A model of ecological responsiveness. Academy of Management Journal, 43(4): 717-736.

Beck, A. C., Campbell, D., \& Shrives, P. J. 2010. Content analysis in environmental reporting research: Enrichment and rehearsal of the method in a British-German context. The British Accounting Review, 42(3): 207-222.

Bowen, F. 2014. After Greenwashing. Cambridge: Cambridge University Press.

Bowen, F., \& Aragon-Correa, J. A. 2014. Greenwashing in Corporate Environmentalism Research and Practice:The Importance of What We Say and Do. Organization \& Environment, 27(2): 107-112.

Brass, D. J., Butterfield, K. D., \& Skaggs, B. C. 1998. Relationships and Unethical Behavior: A Social Network Perspective. Academy of Management Review, 23(1): 14-31.

Bromley, P., \& Powell, W. W. 2012. From Smoke and Mirrors to Walking the Talk: Decoupling in the Contemporary World. Academy of Management Annals, 6(1): 483530.

Brunsson, N. 1993. The necessary hypocrisy. The International Executive, 35(1): 1-9.

Brunsson, N. 2002. The organization of hypocrisy: Talk, decisions and actions in organizations. Copenhagen: Copenhagen Business School.

Brunsson, N. 2003. Organized Hypocrisy. In B. Czarniawska, \& G. Sevon (Eds.), The Norethern Lights - Organization Theory in Scandinavia: 201-222. Copenhagen: Copenhagen Business School Press.

Bryman, A., \& Bell, E. 2003. Business Research Methods. Oxford: Oxford University Press.

Bushman, R. M., Piotroski, J. D., \& Smith, A. J. 2004. What Determines Corporate Transparency? Journal of Accounting Research, 42(2): 207-252.

Catalyst. 2015. How does sustainable banking add up? Sydney, Australia: Catalyst. 
Cavico, D. F. J., \& Mujtaba, D. B. G. 2016. Volkswagen Emissions Scandal: A Global Case Study of Legal, Ethical, and Practical Consequences and Recommendations for Sustainable Management. 2016, 4(2): 9.

Cho, C. H., Laine, M., Roberts, R. W., \& Rodrigue, M. 2015. Organized hypocrisy, organizational façades, and sustainability reporting. Accounting, Organizations and Society, 40: 78-94.

Christensen, L. T., \& Cheney, G. 2015. Peering into Transparency: Challenging Ideals, Proxies, and Organizational Practices. Communication Theory, 25(1): 70-90.

Christensen, L. T., Morsing, M., \& Thyssen, O. 2013. CSR as aspirational talk. Organization, 20(3): 372-393.

Clark Williams, C. 2008. Toward a Taxonomy of Corporate Reporting Strategies. The Journal of Business Communication (1973), 45(3): 232-264.

Commonwealth of Australia. 2019. Final Report: Royal Commission into Misconduct in the Banking, Superannuation and Financial Services Industry. Canberra, Australia: Author.

Compass. 2010. Banks we can believe in. London: Compass.

Cooper, S. M., \& Owen, D. L. 2007. Corporate social reporting and stakeholder accountability: The missing link. Accounting, Organizations and Society, 32(7-8): 649-667.

Crilly, D., Zollo, M., \& Hansen, M. T. 2012. Faking It or Muddling Through? Understanding Decoupling in Response to Stakeholder Pressures. Academy of Management Journal, 55(6): 1429-1448.

Dando, N., \& Swift, T. 2003. Transparency and Assurance Minding the Credibility Gap. Journal of Business Ethics, 44(2): 195-200.

das Neves, J. C., \& Vaccaro, A. 2013. Corporate Transparency: A Perspective from Thomas Aquinas' Summa Theologiae. Journal of Business Ethics, 113(4): 639-648.

Deegan, C. 2002. The legitimising effect of social and environmental disclosures: A theoretical foundation. Accounting, Auditing and Accountability Journal, 15(3): 282-311.

Deegan, C., Rankin, M., \& Voght, P. 2000. Firms' Disclosure Reactions to Major Social Incidents: Australian Evidence. Accounting Forum, 24(1): 101-130.

Delmas, M., \& Toffel, M. 2008. Organizational responses to environmental demands: Opening the black box. Strategic Management Journal, 29(2): 1027-1055.

Delmas, M. A., \& Burbano, V. C. 2011. The Drivers of Greenwashing. California Management Review, 54(1): 64-87. 
Dingwerth, K., \& Eichinger, M. 2010. Tamed Transparency: How Information Disclosure under the Global Reporting Initiative Fails to Empower. Global Environmental Politics, 10(3): 74-96.

Dubbink, W., Graafland, J., \& van Liedekerke, L. 2008. CSR, Transparency and the Role of Intermediate Organisations. Journal of Business Ethics, 82(2): 391-406.

Dumay, J., Guthrie, J., \& Farneti, F. 2010. Gri Sustainability Reporting Guidelines For Public And Third Sector Organizations. Public Management Review, 12(4): 531-548.

Eccles, R. G., Krzus, M. P., Rogers, J., \& Serafeim, G. 2012. The Need for Sector-Specific Materiality and Sustainability Reporting Standards. Journal of Applied Corporate Finance, 24(2): 65-71.

Eisenhardt, K. M. 1989. Building Theories from Case Study Research. Academy of Management Review, 14(4): 532-550.

Etzioni, A. 2010. Is Transparency the Best Disinfectant? Journal of Political Philosophy, 18(4): 389-404.

Fassin, Y., \& Buelens, M. 2011. The hypocrisy-sincerity continuum in corporate communication and decision making: A model of corporate social responsibility and business ethics practices. Management Decision, 49(4): 586-600.

Fernandez-Feijoo, B., Romero, S., \& Ruiz, S. 2014. Effect of Stakeholders' Pressure on Transparency of Sustainability Reports within the GRI Framework. Journal of Business Ethics, 122(1): 53-63.

Flyvbjerg, B. 2001. Making social science matter: Why social inquiry fails and why it can succeed again. Cambridge: Cambridge University Press.

Flyvbjerg, B. 2006. Five Misunderstandings About Case-Study Research. Qualitative Inquiry, 12(2): 219-245.

Foote, D. 2001. The Question of Ethical Hypocrisy in Human Resource Management in the U.K. and Irish Charity Sectors. Journal of Business Ethics, 34(1): 25-38.

Fox, J. 2007. The uncertain relationship between transparency and accountability. Development in practice, 17(4-5): 663-671.

Glynos, J., Klimecki, R., \& Willmott, H. 2015. Logics in policy and practice: a critical nodal analysis of the UK banking reform process AU - Glynos, Jason. Critical Policy Studies, 9(4): 393-415.

Granados, N., Gupta, A., \& Kauffman, R. J. 2006. The impact of IT on market information and transparency: A unified theoretical framework. Journal of the Association for Information Systems, 7(3): 148-178.

Gray, R., \& Milne, M. 2002. Sustainability reporting: Whose kidding whom? Chartered Accountants Journal of New Zealand, 81(6): 66-70. 
Gray, R., Owen, D., \& Adams, C. 1996. Accounting and accountability: Changes and challenges in corporate social and environmental reporting. London: Prentice Hall.

Greenbaum, R. L., Mawritz, M. B., \& Piccolo, R. F. 2015. When Leaders Fail to "Walk the Talk":Supervisor Undermining and Perceptions of Leader Hypocrisy. Journal of Management, 41(3): 929-956.

GRI. 2006. G3 Sustainability Reporting Guidelines. Amsterdam: Author.

Herzig, C., \& Moon, J. 2013. Discourses on corporate social ir/responsibility in the financial sector. Journal of Business Research, 66(10): 1870-1880.

Hibbard, J., Stockard, J., \& Tusler, M. 2003. Does Publicizing Hospital Performance Stimulate Quality Improvement Efforts? Health Affairs, 22(2): 84-94.

Higgins, C., \& Larrinaga, C. 2014. Sustainability reporting: Insights from institutional theory. In J. Unerman, J. Bebbington, \& B. O'Dwyer (Eds.), Sustainability Accounting and Accountability, 2nd ed. London: Routledge.

Higgins, C., Milne, M., \& van Gramberg, B. 2015. The uptake of sustainability reporting in Australia. Journal of Business Ethics, 129(2): 445-468.

Hood, C. 2006. Transparency in historical perspective. In C. Hood, \& D. Heald (Eds.), Transparency: The key to better governance: 3-23. Oxford, England: Oxford University Press.

Jahdi, K. S., \& Acikdilli, G. 2009. Marketing Communications and Corporate Social Responsibility (CSR): Marriage of Convenience or Shotgun Wedding? Journal of Business Ethics, 88(1): 103-113.

Joo, S., Miller, E. G., \& Fink, J. S. 2019. Consumer evaluations of CSR authenticity: Development and validation of a multidimensional CSR authenticity scale. Journal of Business Research, 98: 236-249.

Karp, P. 2016. Timeline: Banking scandals in Australia since 2009, The Guardian.

Klein, N. 2014. This changes everything: Capitalism vs the climate. New York: Simon \& Schuster.

Kolbe, R. H., \& Burnett, M. S. 1991. Content-Analysis Research: An Examination of Applications with Directives for Improving Research Reliability and Objectivity. Journal of Consumer Research, 18(2): 243-250.

Kosack, S., \& Fung, A. 2014. Does Transparency Improve Governance? Annual Review of Political Science, 17(1): 65-87.

KPMG. 1993. KPMG International survey of environmental reporting 1993. Amsterdam: KPMG Environmental Consulting. 
KPMG. 1996. KPMG International survey of environmental reporting 1996. Amsterdam: KPMG Environmental Consulting.

KPMG. 1999. KPMG International survey of environmental reporting 1999. Amsterdam: KPMG Environmental Consulting.

KPMG. 2002. KPMG International survey of corporate sustainability reporting. Amsterdam: KPMG Global Sustainability Services.

KPMG. 2005. International survey of corporate social responsibility reporting 2005. Amsterdam: KPMG International.

KPMG. 2011. The KPMG survey of corporate social responsibility reporting. London: KPMG.

KPMG. 2013. The KPMG survey of corporate responsibility reporting. London: KPMG.

Krippendorff, K. 2013. Content Analysis. An Introduction to Its Methodology California: Sage.

Kulik, B. W. 2005. Agency Theory, Reasoning and Culture at Enron: In Search of a Solution. Journal of Business Ethics, 59(4): 347-360.

Kurtzman, J., Yago, G., \& Phumiwasana, T. 2004. The global costs of opacity - Measuring business and investment risk worldwide. MIT Sloan Management Review, 46(1): 3844.

Laufer, W. S. 2003. Social Accountability and Corporate Greenwashing. Journal of Business Ethics, 43(3): 253-261.

Leo, S., \& Roddam, M. 2017. EXCLUSIVE CBA was "aware" of risk shortfall, The Australian.

Lipson, M., \& Weaver, C. 2008. Varieties of organized hypocrisy, International Studies Association. San Francisco, CA.

Liu, H. 2015. Constructing the GFC: Australian banking leaders during the financial 'crisis'. Leadership 11(4): 424-450.

Loewenstein, G., Sunstein, C. R., \& Golman, R. 2014. Disclosure: Psychology Changes Everything. Annual Review of Economics, 6(1): 391-419.

Lyon, T. P., \& Montgomery, A. W. 2015. The Means and End of Greenwash. Organization \& Environment, 28(2): 223-249.

Meijer, A. 2013. Understanding the Complex Dynamics of Transparency. Public Administration Review, 73(3): 429-439. 
Meise, J. N., Rudolph, T., Kenning, P., \& Phillips, D. M. 2014. Feed them facts: Value perceptions and consumer use of sustainability-related product information. Journal of Retailing and Consumer Services, 21(4): 510-519.

Meyer, J., \& Rowan, B. 1977. Institutional organizations: Formal structure as myth and ceremony. American Journal of Sociology, 83: 340-363.

Miles, M., \& Huberman, M. 1994. Qualitative data analysis: An expanded sourcebook. California: Sage.

Milne, M., \& Gray, R. 2007. Future prospects for corporate sustainability reporting. In J. Unerman, J. Bebbington, \& B. O'Dwyer (Eds.), Sustainability Accounting and Accountability. London: Routledge.

Milne, M., Tregida, H., \& Walton, S. 2004. Playing with magic lanterns: The New Zealand Business Council for Sustainable Development and corporate triple bottom line reporting. Paper presented at the Proceedings of the 4th Asia-Pacific Interdisciplinary Research into Accounting Conference, Singapore.

Mol, A. P. J. 2010. The Future of Transparency: Power, Pitfalls and Promises. Global Environmental Politics, 10(3): 132-143.

Morin, D. 2016. Democratic Accountability During Performance Audits Under Pressure: A Recipe for Institutional Hypocrisy? Financial Accountability \& Management, 32(1): 104-124.

Ngu, S. B., \& Amran, A. 2018. Materiality disclosure in sustainability reporting: fostering stakeholder engagement. Strategic Direction, 34(5): 1-4.

Norman, S. M., Avolio, B. J., \& Luthans, F. 2010. The impact of positivity and transparency on trust in leaders and their perceived effectiveness. The Leadership Quarterly, 21(3): 350-364.

O'Dwyer, B., \& Owen, D. L. 2005. Assurance statement practice in environmental, social and sustainability reporting: a critical evaluation. The British Accounting Review, 37(2): 205-229.

Parguel, B., Benoît-Moreau, F., \& Larceneux, F. 2011. How Sustainability Ratings Might Deter 'Greenwashing': A Closer Look at Ethical Corporate Communication. Journal of Business Ethics, 102(1): 15-28.

Ramus, C. A., \& Montiel, I. 2005. When Are Corporate Environmental Policies a Form of Greenwashing? Business \& Society, 44(4): 377-414.

Roberts, J. 2009. No one is perfect: The limits of transparency and an ethic for 'intelligent' accountability. Accounting, Organizations and Society, 34(8): 957-970.

Scandelius, C., \& Cohen, G. 2016. Achieving collaboration with diverse stakeholders-The role of strategic ambiguity in CSR communication. Journal of Business Research, 69(9): 3487-3499. 
Schmulow, A., Fairweather, K., \& Tarrant, J. 2019. Restoring Confidence in Consumer Financial Protection Regulation in Australia: A Sisyphean Task? Federal Law Review, 0(0): 0067205X18816240.

Schnackenberg, A. K., \& Tomlinson, E. C. 2016. Organizational Transparency. Journal of Management, 42(7): 1784-1810.

Scholtens, B. J. J. o. B. E. 2009. Corporate Social Responsibility in the International Banking Industry. Journal of Business Ethics, 86(2): 159-175.

Siano, A., Vollero, A., Conte, F., \& Amabile, S. 2017. "More than words": Expanding the taxonomy of greenwashing after the Volkswagen scandal. Journal of Business Research, 71: 27-37.

Slawinski, N., \& Bansal, P. 2015. Short on Time: Intertemporal Tensions in Business Sustainability. Organization Science, 26(2): 531-549.

Strathern, M. 2000. The Tyranny of Transparency. British Educational Research Journal, 26(3): 309-321.

Thompson, J. 1967. Organizations in action. New York NY: McGraw-Hill.

Tietenberg, T. 1998. Disclosure Strategies for Pollution Control. Environmental and Resource Economics, 11(3): 587-602.

van Dorp, K. J. 2003. Beef labelling: the emergence of transparency. Supply Chain Management: An International Journal, 8(1): 32-40.

van Zyl, A. 2014. How Civil Society Organizations Close the Gap between Transparency and Accountability. Governance, 27(2): 347-356.

Vishwanath, T., \& Kaufmann, D. 2001. Toward Transparency: New Approaches and Their Application to Financial Markets. The World Bank Research Observer, 16(1): 41-57.

Vorauer, J. D., \& Claude, S.-D. 1998. Perceived Versus Actual Transparency of Goals in Negotiation. Personality and Social Psychology Bulletin, 24(4): 371-385.

Wagner, T., Lutz, R., \& Weitz, B. 2009. Corporate hypocrisy: Overcoming the threat of inconsistent corporate social responsibility perceptions. Journal of Marketing, 73(6): 77-91.

Walker, K., \& Wan, F. 2012. The Harm of Symbolic Actions and Green-Washing: Corporate Actions and Communications on Environmental Performance and Their Financial Implications. Journal of Business Ethics, 109(2): 227-242.

Westpac Banking Corporation. 2015. What's important to you is important to us: 2015 Westpac Group Sustainability Performance Report. Sydney: Author.

Wishart, D., \& Wardrop, A. 2018. What can the Banking Royal Commission achieve: Regulating for good corporate culture? Alternative Law Journal, 43(2): 81-88. 
Yin, R. 1984. Case study research: Design and Methods. Beverley Hills, CA: Sage.

\section{Sustainability Reports Reviewed}

VicSuper

- VicSuper Full Performance Report 2011: https://www.vicsuper.com.au/ /media/files/pdfs-anddownloads/other/reports/2011-full-report.pdf?la=en. Accessed 20 March 2018.

- VicSuper Full Performance Report 2012: https://www.vicsuper.com.au/ /media/files/pdfs-anddownloads/other/reports/2012-full-report.pdf?la=en. Accessed 20 March 2018.

- VicSuper Annual Performance Report 2013: https://www.vicsuper.com.au/ /media/files/pdfsand-downloads/other/reports/2013performancereport.pdf?la=en. Accessed 20 March 2018.

- VicSuper Annual Performance Report 2014: https://www.vicsuper.com.au/ /media/files/pdfsand-downloads/other/reports/performance-report-2014.pdf?la=en. Accessed 20 March 2018.

- VicSuper Annual Report 2015: https://www.vicsuper.com.au/ /media/files/pdfs-anddownloads/other/campaigns/annual-report-2015/annual-report-2015.pdf?la=en. Accessed 20 March 2018.

Westpac

- Westpac Group Annual Review and Sustainability Report 2011: https://www.westpac.com.au/content/dam/public/wbc/documents/pdf/aw/sustainability/2011 Annual Review and Sustainability Report.pdf. Accessed 20 March 2018.

- Westpac Group Annual Review and Sustainability Report 2012: https://www.westpac.com.au/content/dam/public/wbc/documents/pdf/aw/sustainability/2012 Annual Review and Sustainability Report.pdf. Accessed 20 March 2018.

- Westpac Group Annual Review and Sustainability Report 2013: The strength we've built today: https://www.westpac.com.au/content/dam/public/wbc/documents/pdf/aw/sustainability/2013 Annual Review and Sustainability Report.pdf. Accessed 20 March 2018.

- Westpac Group Annual Review and Sustainability Report 2014: This is what we've delivered: https://www.westpac.com.au/content/dam/public/wbc/documents/pdf/aw/sustainability/2014 \%20Annual\%20Review\%20and\%20Sustainability\%20report.pdf. Accessed 20 March 2018.

- Westpac Group Sustainability Performance Report 2015: What's important to you is important to us:

https://www.westpac.com.au/content/dam/public/wbc/documents/pdf/aw/sustainability/2015 \%20Westpac\%20Group\%20Sustainability\%20Performance\%20Report.pdf. Accessed 20 March 2018.

Bank Australia

- 2012 Online Report: http://www.bankmecuannualreport2012.com.au/annual-report/about-thisreport\#.XK6MrsRS-Uk. Accessed 20 March 2018.

- 2013 Corporate Report: http://www.bankmecuannualreport2013.com.au/. Accessed 20 March 2018.

- 2014 Corporate Report: Our Annual Footprint: http://bankmecu2014corporatereport.com.au/. Accessed 20 March 2018.

- 2015 Corporate Report: Mutual Prosperity: https://bankaust.com.au/corporatereports/corporate-report-2015/corporate-report/. Accessed 20 March 2018. 
Appendix A: Broad topics of information shared in sustainability reports

\begin{tabular}{|c|c|c|c|c|c|}
\hline & & & Year & & \\
\hline Company & 2011 & 2012 & 2013 & 2014 & 2015 \\
\hline \multirow{9}{*}{$\begin{array}{l}\text { Bank } \\
\text { Australia }\end{array}$} & & Performance highlights & Performance highlights & Chariman/CEO letter & Chariman/CEO letter \\
\hline & & Chariman/CEO letter & Chariman/CEO letter & Performance highlights & $\begin{array}{l}\text { About the bank (values \& } \\
\text { purpose) }\end{array}$ \\
\hline & & $\begin{array}{l}\text { About the bank (values \& } \\
\text { purpose) }\end{array}$ & $\begin{array}{l}\text { About the bank (values \& } \\
\text { purpose) }\end{array}$ & & Human capital \\
\hline & & $\begin{array}{l}\text { Businesses/Products \& } \\
\text { services }\end{array}$ & $\begin{array}{l}\text { Businesses/Products \& } \\
\text { services }\end{array}$ & & $\begin{array}{r}\text { Environmental } \\
\text { stewardship }\end{array}$ \\
\hline & & Social capital & Social capital & & $\begin{array}{l}\text { Businesses/Products \& } \\
\text { services }\end{array}$ \\
\hline & & Leadership \& governance & Leadership \& governance & & Social capital \\
\hline & & $\begin{array}{r}\text { Environmental } \\
\text { stewardship }\end{array}$ & $\begin{array}{r}\text { Environmental } \\
\text { stewardship }\end{array}$ & & About the report \\
\hline & & Balance sheet \& Tax & Balance sheet \& Tax & & Leadership \& governance \\
\hline & & & & & $\begin{array}{l}\text { Global Reporting } \\
\text { Initiative Index }\end{array}$ \\
\hline \multirow[t]{3}{*}{ VicSuper } & Chairman/CEO letter & Chairman/CEO letter & $\begin{array}{l}\text { About the bank (values \& } \\
\text { purpose) }\end{array}$ & About the report & About the report \\
\hline & $\begin{array}{l}\text { About the bank (values \& } \\
\text { purpose) }\end{array}$ & $\begin{array}{l}\text { About the bank (values \& } \\
\text { purpose) }\end{array}$ & About the report & $\begin{array}{l}\text { About the bank (values \& } \\
\text { purpose) }\end{array}$ & $\begin{array}{l}\text { About the bank (values \& } \\
\text { purpose) }\end{array}$ \\
\hline & About the report & About the report & Chairman/CEO letter & Performance highlights & Performance highlights \\
\hline
\end{tabular}




\begin{tabular}{|c|c|c|c|c|c|}
\hline & News & News & News & Chairman/CEO letter & Chairman/CEO letter \\
\hline & Social capital & Performance highlights & $\begin{array}{l}\text { Businesses/Products \& } \\
\quad \text { services }\end{array}$ & Regulatory environment & Regulatory environment \\
\hline & $\begin{array}{l}\text { Environmental } \\
\text { stewardship }\end{array}$ & $\begin{array}{l}\text { Businesses/Products \& } \\
\text { services }\end{array}$ & $\begin{array}{l}\text { Summary financial } \\
\text { statements }\end{array}$ & $\begin{array}{l}\text { Business model (policy \& } \\
\text { approach) }\end{array}$ & $\begin{array}{l}\text { Business model (policy \& } \\
\quad \text { approach) }\end{array}$ \\
\hline & Human capital & $\begin{array}{l}\text { Business model (policy \& } \\
\text { approach) }\end{array}$ & $\begin{array}{l}\text { Business model (policy \& } \\
\quad \text { approach) }\end{array}$ & $\begin{array}{l}\text { Summary financial } \\
\text { statements }\end{array}$ & $\begin{array}{l}\text { Summary financial } \\
\text { statements }\end{array}$ \\
\hline & $\begin{array}{l}\text { Summary financial } \\
\text { statements }\end{array}$ & Social capital & Social capital & Leadership \& governance & $\begin{array}{l}\text { Businesses/Products \& } \\
\quad \text { services }\end{array}$ \\
\hline & Leadership \& governance & $\begin{array}{l}\text { Environmental } \\
\text { stewardship }\end{array}$ & Human capital & $\begin{array}{l}\text { Businesses/Products \& } \\
\text { services }\end{array}$ & Social capital \\
\hline & $\begin{array}{l}\text { Business model (policy \& } \\
\text { approach) }\end{array}$ & Human capital & $\begin{array}{l}\text { Environmental } \\
\text { stewardship }\end{array}$ & Social capital & Leadership \& governance \\
\hline & $\begin{array}{l}\text { Businesses/Products \& } \\
\text { services }\end{array}$ & $\begin{array}{l}\text { Summary financial } \\
\text { statements }\end{array}$ & Leadership \& governance & Human capital & Human capital \\
\hline & Performance highlights & Leadership \& governance & & & \\
\hline & $\begin{array}{l}\text { Commitments for year } \\
\text { ahead }\end{array}$ & Assurance & & & \\
\hline & Assurance & & & & \\
\hline Westpac & Performance highlights & Performance highlights & Performance highlights & Performance highlights & Performance highlights \\
\hline & News (recognition) & Chairman/CEO letter & Chairman/CEO letter & Chairman/CEO letter & Chairman/CEO letter \\
\hline & $\begin{array}{l}\text { Strategy \& Sustainability } \\
\text { (vision, strategy \& } \\
\text { approach, material } \\
\text { issues) }\end{array}$ & $\begin{array}{l}\text { Strategy \& Sustainability } \\
\text { (vision, strategy \& } \\
\text { approach, material } \\
\text { issues) }\end{array}$ & $\begin{array}{l}\text { About the bank (values \& } \\
\text { purpose) }\end{array}$ & $\begin{array}{l}\text { About the bank (values \& } \\
\text { purpose) }\end{array}$ & $\begin{array}{l}\text { Business model (policy \& } \\
\text { approach) }\end{array}$ \\
\hline
\end{tabular}




\begin{tabular}{|c|c|c|c|c|}
\hline Chairman/CEO letter & $\begin{array}{l}\text { Businesses/Products \& } \\
\quad \text { services }\end{array}$ & $\begin{array}{l}\text { Strategy (vision, } \\
\quad \text { approach, priorities) }\end{array}$ & $\begin{array}{l}\text { Strategy (vision, } \\
\quad \text { approach, priorities) }\end{array}$ & Human capital \\
\hline $\begin{array}{l}\text { Businesses/Products \& } \\
\text { services }\end{array}$ & Human capital & $\begin{array}{l}\text { Businesses/Products \& } \\
\text { services }\end{array}$ & $\begin{array}{l}\text { Business model (policy \& } \\
\text { approach) }\end{array}$ & $\begin{array}{l}\text { Environmental } \\
\text { stewardship }\end{array}$ \\
\hline Human capital & Social capital & Human capital & $\begin{array}{l}\text { Businesses/Products \& } \\
\text { services }\end{array}$ & Social capital \\
\hline Social capital & $\begin{array}{l}\text { Sustainability objectives } \\
\quad \& \text { performance }\end{array}$ & Social capital & Human capital & $\begin{array}{l}\text { Five Year Summary } \\
\text { (financial \& non- } \\
\text { financial) }\end{array}$ \\
\hline About the report & $\begin{array}{l}\text { Environmental } \\
\text { stewardship }\end{array}$ & $\begin{array}{l}\text { Sustainability objectives } \\
\& \text { performance }\end{array}$ & $\begin{array}{l}\text { Environmental } \\
\text { stewardship }\end{array}$ & Leadership \& governance \\
\hline $\begin{array}{l}\text { Sustainability objectives } \\
\& \text { performance }\end{array}$ & $\begin{array}{l}\text { Five Year Summary } \\
\text { (financial \& non- } \\
\text { financial) }\end{array}$ & $\begin{array}{l}\text { Environmental } \\
\text { stewardship }\end{array}$ & Social capital & $\begin{array}{l}\text { Information for } \\
\text { shareholders \& } \\
\text { Contact details }\end{array}$ \\
\hline $\begin{array}{l}\text { Five Year Summary } \\
\text { (financial \& non- } \\
\text { financial) }\end{array}$ & Leadership \& governance & $\begin{array}{l}\text { Five Year Summary } \\
\text { (financial \& non- } \\
\text { financial) }\end{array}$ & & \\
\hline Leadership \& governance & $\begin{array}{l}\text { Information for } \\
\text { shareholders \& } \\
\text { Contact details }\end{array}$ & Leadership \& governance & & \\
\hline $\begin{array}{l}\text { Information for } \\
\text { shareholders \& } \\
\text { Contact details }\end{array}$ & & $\begin{array}{l}\text { Information for } \\
\text { shareholders \& } \\
\text { Contact details }\end{array}$ & & \\
\hline
\end{tabular}




\begin{tabular}{ll}
\hline Date & Scandal $^{6}$ \\
\hline 6 April 2016 & Former ANZ planner jailed for stealing almost \$1m \\
7 March 2016 & CommInsure chief medical officer blows whistle on unethical practices \\
20 January 2016 & Westpac paid \$1m fine over credit limit practices \\
15 January 2016 & Two dismissed ANZ traders caim culture of sex, drugs and alcohol \\
18 December 2015 & Asic permanently banned former WA branch bank manager \\
25 November 2015 & CBA issues \$80m refund \\
29 October 2015 & Westpac offered refunds over unneeded insurance cover \\
15 October 2015 & Asic banned Westpac subsidiary answer for unauthorised transfers \\
24 July 2015 & NAB wealth management to pay \$25m compensation \\
1 October 2014 & NAB fined \$10,200 for product disclosure statement \\
24 September 2014 & Asic fined NAB \$40,800 over loan ads \\
17 September 2014 & Westpac fined \$20,400 for product disclosure statement \\
23 December 2013 & NAB gives enforceable undertaking over possible misconduct causing share \\
& price spike \\
17 December 2013 & Two CBA companies review handling of client money \\
10 November 2012 & NAB settles sub prime mortgage securities class action for \$115m \\
14 September 2012 & CBA agreed to \$136m for compensation over Storm Financial \\
7 March 2012 & CBA accepts enforceanble undertaking due to credit limit consent concerns \\
31 March 2011 & Former Macquarie fund manager jailed over insider trading \\
\hline
\end{tabular}

Table 2: Characteristics of case organisations

\begin{tabular}{|c|c|c|c|}
\hline Organisation & $\begin{array}{l}\text { Financial Services } \\
\text { Type }\end{array}$ & $\begin{array}{l}\text { Size (Employees } \\
\text { in 2015) }\end{array}$ & Reporting Experience \\
\hline Westpac & $\begin{array}{l}\text { Large publicly owned } \\
\text { commercial bank }\end{array}$ & 39,754 & $\begin{array}{l}\text { Social Impact Reporting from } 2002 \\
\text { Stakeholder Impact Report from } 2004 \\
\text { Community Involvement Report from } 2007 \\
\text { Sustainability Report from } 2009\end{array}$ \\
\hline VicSuper & $\begin{array}{l}\text { Member-owned } \\
\text { superannuation fund }\end{array}$ & 241 & Sustainability Reports from 2004 \\
\hline Bank Australia & Financial co-operative & $335^{7}$ & $\begin{array}{l}\text { Corporate Report from } 2011 \text { (incorporating } \\
\text { sustainability report) }\end{array}$ \\
\hline
\end{tabular}

${ }^{6}$ Abbreviations below refer to Australian Securities and Investments Commission (ASIC); Australia and New Zealand Banking Group (ANZ); Commonwealth Bank of Australia (CBA); National Australia Bank (NAB)

${ }^{7}$ Figure does not include Directors or those on workers compensation. 
Table 3: Codebook for analysing the reports - coding themes for transparency dimensions. Derived from Schnackenberg and Tomlinson (2016).

\begin{tabular}{|c|c|c|c|}
\hline $\begin{array}{l}\text { Framework } \\
\text { dimension }\end{array}$ & Coding themes & Description & Sources of hypocrisy \\
\hline \multirow[t]{4}{*}{ Disclosure } & Relevancy & $\begin{array}{l}\text { The emphasis on the various } \\
\text { topics in the report is } \\
\text { proportionate to their relative } \\
\text { materiality for the } \\
\text { organisation }\end{array}$ & $\begin{array}{l}\text { Sharing of irrelevant information } \\
\text { that has low materiality to the } \\
\text { organisation }\end{array}$ \\
\hline & Observability & $\begin{array}{l}\text { Information allows users to } \\
\text { identify changes and analyse } \\
\text { trends in performance over } \\
\text { time and be compared to } \\
\text { appropriate benchmarks }\end{array}$ & $\begin{array}{l}\text { Inconsistency in what information } \\
\text { is shared from one year to the } \\
\text { next }\end{array}$ \\
\hline & Completeness & $\begin{array}{l}\text { An account of the entire } \\
\text { organisation, reflecting } \\
\text { positive and negative } \\
\text { performance, and does not } \\
\text { omit information that would } \\
\text { influence or inform users } \\
\text { assessments or decisions }\end{array}$ & $\begin{array}{l}\text { Provides an incomplete account } \\
\text { of the organisation }\end{array}$ \\
\hline & Timeliness & $\begin{array}{l}\text { Information shared indicates the } \\
\text { time period to which it relates } \\
\text { and when it will be updated }\end{array}$ & $\begin{array}{l}\text { Asynchronous and irregular } \\
\text { sharing of information }\end{array}$ \\
\hline \multirow[t]{4}{*}{ Clarity } & Coherence & $\begin{array}{l}\text { Communication is logical and } \\
\text { consistent, connecting } \\
\text { information to the } \\
\text { organisation's strategy and } \\
\text { practice and industry } \\
\text { performance }\end{array}$ & $\begin{array}{l}\text { Illogical and inconsistent, failing } \\
\text { to connect to strategy and } \\
\text { practice and industry } \\
\text { performance }\end{array}$ \\
\hline & Interpretability & $\begin{array}{l}\text { Information is explained clearly } \\
\text { and reduces ambiguity for } \\
\text { users }\end{array}$ & $\begin{array}{l}\text { Ambiguity about information } \\
\text { shared due to a lack of } \\
\text { context provided }\end{array}$ \\
\hline & Understandibility & $\begin{array}{l}\text { Information avoids excessive } \\
\text { unnecessary use of technical } \\
\text { terms and acronyms that are } \\
\text { likely to be unfamiliar to users }\end{array}$ & $\begin{array}{l}\text { Overuse of technical terms or } \\
\text { acronyms without clear } \\
\text { explanation }\end{array}$ \\
\hline & Comprehensibility & $\begin{array}{l}\text { Information is simple enough to } \\
\text { be easily apprehended by } \\
\text { users }\end{array}$ & $\begin{array}{l}\text { Difficult to comprehend the } \\
\text { meaning from information } \\
\text { shared }\end{array}$ \\
\hline \multirow[t]{4}{*}{ Accuracy } & Validity & $\begin{array}{l}\text { Information is well-founded, } \\
\text { reflecting the reality it claims } \\
\text { to represent }\end{array}$ & Claims are unfoundedly contrived \\
\hline & Precision & $\begin{array}{l}\text { Information measurement } \\
\text { techniques and bases for } \\
\text { calculations are adequately } \\
\text { described, and can be } \\
\text { replicated with similar results }\end{array}$ & $\begin{array}{l}\text { Limited or overly technical } \\
\text { explanation of calculation or } \\
\text { measurement techniques }\end{array}$ \\
\hline & Correctness & $\begin{array}{l}\text { Margin of error is not sufficient to } \\
\text { substantially influence the } \\
\text { ability of users to reach } \\
\text { appropriate and informed } \\
\text { conclusions on performance }\end{array}$ & Significant margin of error \\
\hline & Reliability & $\begin{array}{l}\text { Information shared can be } \\
\text { depended on, free of bias and } \\
\text { distortion }\end{array}$ & $\begin{array}{l}\text { Distortion or bias in information } \\
\text { shared }\end{array}$ \\
\hline
\end{tabular}


Table 4: Summary of VicSuper's environmental, social and governance (ESG) engagement with companies between 2011-2015

\begin{tabular}{|c|c|c|c|c|c|}
\hline & Australian Co & mpanies & International & Companies & \\
\hline $\begin{array}{l}\text { Report } \\
\text { Year }\end{array}$ & $\begin{array}{l}\text { Companies } \\
\text { engaged }\end{array}$ & $\begin{array}{l}\text { ESG issues } \\
\text { discussed }\end{array}$ & $\begin{array}{l}\text { Companies } \\
\text { engaged }\end{array}$ & $\begin{array}{l}\text { ESG issues } \\
\text { discussed }\end{array}$ & Totals \\
\hline 2011 & 35 & 9 & 612 & 1924 & $\begin{array}{l}647 \text { companies engaged } \\
1,933 \text { ESG issues }\end{array}$ \\
\hline 2012 & $110[53]^{8}$ & & 430 & 925 & $\begin{array}{l}540 \text { companies engaged } \\
925 \text { ESG issues (Intnl only) }\end{array}$ \\
\hline 2013 & 51 [67] & 213 & 455 & 975 & $\begin{array}{l}506 \text { companies engaged } \\
1,430 \text { ESG issues }\end{array}$ \\
\hline 2014 & Not disclosed & & Not disclosed & & $\begin{array}{l}577 \text { engagement meetings } \\
1,392 \text { ESG issues } \\
1,848 \text { meetings in which voting } \\
\text { occurred } \\
7 \% \text { votes against management } \\
\text { resolutions } \\
93 \% \text { votes for management } \\
\text { resolutions }\end{array}$ \\
\hline 2015 & Not disclosed & & Not disclosed & & $\begin{array}{l}742 \text { engagement meetings } \\
1,572 \text { ESG issues } \\
1,855 \text { meeting in which voting } \\
\text { occurred } \\
7.3 \% \text { votes against management } \\
\text { resolutions } \\
91.3 \% \text { votes for management } \\
\text { resolutions }\end{array}$ \\
\hline
\end{tabular}

${ }^{8}$ The number in [brackets] is what was listed as the preceding year's comparative data 